\title{
Reflets
}

Revue ontaroise d'intervention sociale et communautaire

\section{Shakespeare aussi}

\section{Carole Labrèche}

Volume 1, numéro 2, automne 1995

La santé communautaire en Ontario français : défis et espoirs

URI : https://id.erudit.org/iderudit/026095ar

DOI : https://doi.org/10.7202/026095ar

Aller au sommaire du numéro

Éditeur(s)

Reflets : Revue ontaroise d'intervention sociale et communautaire

ISSN

1203-4576 (imprimé)

1712-8498 (numérique)

Découvrir la revue

Citer ce document

Labrèche, C. (1995). Shakespeare aussi. Reflets, 1(2), 261-261.

https://doi.org/10.7202/026095ar

Tous droits réservés (C) Reflets : Revue ontaroise d'intervention sociale et communautaire, 1995

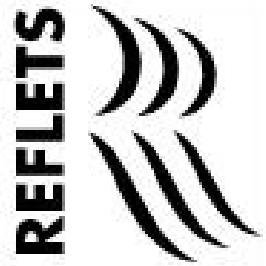

Ce document est protégé par la loi sur le droit d'auteur. L'utilisation des services d'Érudit (y compris la reproduction) est assujettie à sa politique d'utilisation que vous pouvez consulter en ligne.

https://apropos.erudit.org/fr/usagers/politique-dutilisation/ 


\section{Shakespeare aussi}

\section{C arole L abrèche}

- What brings you here?

- Le taxi, M 'sieur.

- $\quad$ o, no, no. I meant: why are you here?

- Ah! O ui. Let's see: unfinished business and sleepless nights.

J'ai also perdu ma job pisj'suis bien découragée

Wait une minute, quand j'suis malade

j'suis par bilingue. M y heart can't translate

I'll need un dictionnaire for each of my tears.

Comment ça mon docteur speaks only l'English?

On well, it is so triste to see

un psychiatrist who can't understand

la langue de M olière

Comme de raison Shakespeare

must have been in hospital too

W here else qu'à I'hôpital

Could he have got the idea:

«To beep or not to beep

that is the question» 